\title{
Second-life retailing: a reverse supply chain perspective
}

Article

Accepted Version

Beh, L.-S., Ghobadian, A., He, Q., Gallear, D. and O'Regan, N. (2016) Second-life retailing: a reverse supply chain perspective. Supply Chain Management: An International Journal, 21 (2). pp. 259-272. ISSN 1359-8546 doi: https://doi.org/10.1108/SCM-07-2015-0296 Available at https://centaur.reading.ac.uk/62914/

It is advisable to refer to the publisher's version if you intend to cite from the work. See Guidance on citing.

Published version at: http://dx.doi.org/10.1108/SCM-07-2015-0296

To link to this article DOI: http://dx.doi.org/10.1108/SCM-07-2015-0296

Publisher: Emerald

All outputs in CentAUR are protected by Intellectual Property Rights law, including copyright law. Copyright and IPR is retained by the creators or other copyright holders. Terms and conditions for use of this material are defined in the End User Agreement.

\section{www.reading.ac.uk/centaur}

\section{CentAUR}

Central Archive at the University of Reading 
Reading's research outputs online 
Loo-See Beh

Faculty of Economics \& Administration, University of Malaya, Malaysia

Abby Ghobadian

Henley Business School, University of Reading, UK

Qile $\mathrm{He}$

Coventry Business School, Coventry University, UK

David Gallear

Brunel Business School, Brunel University

Nicholas O’Regan

Faculty of Business and Law, University of the West of England, UK

Corresponding author: Abby Ghobadian (abby.ghobadian@henley.ac.uk)

Second-life retailing: a reverse supply chain perspective 


\begin{abstract}
Purpose - We examine the role of entrepreneurial business models in the reverse supply chain of apparel/fashion retailers. The paper offers an alternative approach to the "return to the point of origin" prevalent in the reverse chain of manufacturers but less technically and economically feasible in the case of apparel/fashion retailers. This approach, second-life retailing, not only reduces waste but also democratises consumption.
\end{abstract}

Design/methodology/approach - The paper is based on an extensive literature review, semistructured interviews with managers of two second-life retailers in Malaysia, and observations of a number of stores.

Findings - Using the business model canvas we demonstrate the essential characteristics of second-life retailers. Retailers in our study, unlike retailers in the developed world, combine traditional business models with off-price retailing. There is no clear demarcation between the forward and reverse supply chain used to manage first and second hand retailing.

Practical implications - The paper demonstrates the potential of innovative business models in the reverse supply chain. It encourages managers to look beyond the "return to the point of origin" and seek imaginative alternatives. Such alternatives potentially could result in additional revenue, enhanced sustainability, and democratisation of consumption meeting triple bottom line objectives.

Originality/value - This paper highlights the importance and relevance of entrepreneurial business models in addressing reverse supply chain, demonstrating this with the aid of two Malaysian off-price retailers. It also contributes to our nascent knowledge by focusing on emerging markets.

Keywords: Reverse logistics, Retailing, Sustainability, Business model, Sustainable supply chain

Paper type: Case study 


\section{Introduction}

Supply chain management (SCM) plays a critical role not only in enhancing competitiveness but also in addressing responsible behaviour across all stages of the supply chain. SCM is a relatively young discipline that extends logistics by integrating the management of operations with that of material and information flow (Handfield and Nichols, 1999). The initial focus of SCM was economic sustainability, based on the premise that an integrated and efficient supply chain potentially minimises monetary risks and increases profits (Fawcett et al., 2008a, 2008b). However, the business environment has changed greatly bringing with it environmental and corporate social responsibility considerations.

The behaviour of firms with regard to the environment and corporate responsibility plays an increasing role in determining consumer choice (Mohr and Webb, 2005; Hillenbrand et al., 2013). Today, firms that ignore sustainability and corporate responsibility do so at their peril (Utting, 2005; Sweeney and Coughlan, 2008; Ghobadian et al., 2015). The reason for this is twofold. First, technologies such as the World Wide Web, combined with 24-hour news, offer consumers unprecedented access to information, including that of firm behaviour (Teece, 1996). Second, the combination of natural events, such as unprecedented weather patterns; wide coverage of the climate change debate; the efforts of non-governmental organisations (NGOs); disasters, such as the fatal fire in a Bangladesh garment factory (Harris, 2013); and better education have raised environmental and corporate responsibility awareness among consumers and stakeholders (Steurer et al., 2012).

Supply chain management has not been immune from the increased attention paid by consumers to the environmental and corporate responsibility behaviour of firms. Other factors heightening the attention managers pay to supply chains' environmental and social impact include: tougher environmental regulation; regulations designed to protect stakeholders, such as employees, customers and suppliers; NGO's attention; and the rise of social media giving greater visibility to poor practices increasing the cost of irresponsible business. Hence, not surprisingly, economic sustainability has been augmented with social and environmental sustainability giving rise to green supply chain management (GSCM) and sustainable supply chain management (SSCM) concepts. Sustainable supply chain management is a rapidly evolving field incorporating the ecological and social dimensions of businesses as well as economic sustainability (Linton et al., 2007, Svensson, 2007, Seuring and Müller, 2008; Carter and Easton, 2011; Sarkis et al., 2011; Abbasi and Nilsson, 2012) 
and is potentially an important discipline for establishing how to integrate environmental and social considerations and practices in order to achieve the goal of sustainability (Seuring and Müller, 2008; Ashby et al., 2012).

Researchers are increasingly attracted to SSCM and a number of publications address concepts such as reverse logistics (Klausner and Hendrickson, 2000; Schwartz, 2000; Meade and Sarkis, 2002), closed-looped supply chains (Guide et al., 2003; Savaskan et al., 2004; Chuang et al., 2014) and the greening of supply (Ashby et al., 2012; Ahi and Searcy, 2013). However, as Ashby et al. (2012) noted, the manufacturing sector provides the backdrop for the great majority of the current SSCM research.

The service reverse supply chain is more complex than the manufacturing reverse supply chain because the output of the service sector consists of a bundle comprising tangible and intangible components (Davis and Heineke, 2003). Logically therefore, the greater the intangible component of a service firm's output the lower is the potential for reversing the tangible components of supply chain. For this reason we concentrate on services with a significant tangible output. More specifically, we focus on the retail trade concentrating on retailers of apparel and fashion because; it is a significant sector in both developed and emerging economies (Hawley, 2006); it can have a complex reverse supply chain; effective management of the forward and reverse supply chains has a significant impact on its profitability (Abraham, 2011); and there are opportunities to integrate environmental and social considerations (Emmelhainz and Adams, 1999; Zhou, 2009). Based on discussions with a number of major UK apparel retailers, a review of the trade journals and work by Schwartz (2000), Tibben-Lembke and Rogers (1998) and Dowlatshahi (2000), we have mapped out the typical retail forward and reverse supply chains of apparel and fashion retailers (see Figure 1).

[Insert Figure 1 about here]

The aim of this paper is to examine the reverse supply chain of the apparel and fashion retailers, focusing on a second-life retail business model built on offering discarded stock. Second-life retailers rely on a business model designed to extend the life of the apparel and fashion goods typically sold by the traditional primary retailers. The classic recycling of material, which is possible in the manufacturing sector, is less feasible and economical for apparel and fashion retailers (Hawley, 2006). Hence, classic reverse logistics and closed-loop 
supply chains based on reversing goods back to the point of origin for refurbishment or recovery of valuable elements is less common (Hawley, 2006). For example, a number of large retailers, such as Marks \& Spencer and H\&M, have experimented with converting used apparel into raw materials for use in the manufacture of new apparel. However, they have abandoned the idea for the time being because the technology to convert used apparel into useable raw material is underdeveloped. This is not to say that converting used apparel back into raw materials is not possible or that it does not take place, but it is important to appreciate that such opportunities are restricted. On the other hand, the apparel and fashion reverse supply chain supports second-life/second-hand retailing business models that bring to market overruns and seconds of traditional retailers/manufacturers or consumers' used apparel (Hvass, 2015). More importantly, the second-life business model not only reduces waste but it also democratises consumption - thus addressing both tenets of the World Commission on Environment and Development (WCED, 1987, p. 43). Offering goods and products that are at a stage of either maturity or decline in their life cycles to a new set of customers contributes to the sustainability initiatives of the firm, provides for improving the performance of the business in secondary markets (Meyer, 1999) and democratises consumption. Secondary markets constitute part of ethical consumerism's attempts to minimise or eliminate the harmful effects to the environment or society by reducing disposal (Brace-Govan and Binay, 2010) and making goods available at affordable prices to a broader consumer base.

In this paper we examine the opportunities for the secondary markets of off-price retailers and outlet stores with case examples of two major retailers in Malaysia: F.O.S (Factory Outlet Store) and Reject Shop (RS). We use the Business Model Canvas (Osterwalder and Pigneur, 2010) to structure our case studies because it provides a comprehensive picture of a business. We draw our cases from Malaysia because it is an emerging market where environmental and corporate responsibility is gaining prominence. We contribute to the emerging literature of the service reverse supply chain by identifying and examining business models designed to extend the life of apparel and fashion goods, reducing waste and democratising consumption. This adds a different and a new dimension to the service reverse supply chain. We examine the key characteristics of second-life retailers, such as their value propositions, infrastructure, customers and finances, for the specific niche of extending the life of products in secondary retail markets. This is an understudied area, except with regard to studies examining electronic waste recycling (Nagurney and Toyasaki, 2005), electronic 
waste management practices, environmental management and implications of sustainability (Corbett and Kleindorfer, 2003; Kleindofer et al., 2005).

The paper is structured as follows. In the next section we review the key relevant literature and arguments establishing a link to apparel/fashion retailing. This is followed by theoretical considerations, discussion of business models and articulation of methodology. This is then followed by case analysis and conclusions.

\section{The supply chain and sustainability with a focus on retailers}

In general, a supply chain consists of a number of partners or stakeholders, including suppliers, manufacturers, distributors, retailers and customers, and involves materials, resources, information and activities or flows within functional boundaries as well as the relationship between bounded stakeholders. Thus the business process involves the planning and execution of activities within the links of operational relationships.

Reverse logistics (Guidini, 1996) aims at improving the exploitation of used products through recycling, remanufacturing or other forms of recovery; recapturing the value or value creation with new production systems that generate new markets and lead to a reduction in environmental degradation (Lee et al., 1995). Products may reverse direction in the supply chain for a variety of reasons, such as manufacturing returns, commercial returns (B2B and B2C), product recalls, warranty returns, service returns, end-of-use returns and end-of-life returns.

The reverse logistics function in supply chain management has received increasing attention given its potential and value. Reverse logistics has two dominant end purposes for returned materials: reconditioning (high-value recovery) or recycling (low to no-value recovery) (Simpson, 2010). Both are more relevant to the manufacturing sector than the service sector. The alternative to "reconditioning" and to a large extent "re-cycling" in apparel and fashion retailing is second-life retailing based on an alternative retailing business model. As indicated earlier, environmental considerations have led to concerns with recovery of used products or their safe disposal through reverse supply chain systems. In this paper we demonstrate that new entrepreneurial business models designed to seek new potential markets for unwanted/second apparel/fashion stocks offer a different route to extending the life of apparel/fashion goods, reducing waste and creating value. 
The term "sustainability" is commonly defined as utilising resources to meet the needs of the present without compromising future generations' ability to meet their own needs (WCED, 1987). The concept is now broadened beyond its original environmental focus to encompass economic and social considerations as well. Business organisations more and more are concerned with the life-cycle implications of their decisions (Hu and Bidanda, 2009; Isaksson et al., 2010), hence the management of supply chains is receiving increased attention simply because it is a dynamic process that includes the continuous flow of materials, funds and information across multiple functional areas within and between supply chain members (Jain et al., 2009). In broad terms, GSCM and SSCM encompass resource saving, product recycling or reuse, green design and harmful material reduction to improve the environmental performance of supply chains in the industry (Holt and Ghobadian, 2009; Lau, 2011, Kumar et al., 2014).

Theory describing reverse logistics is less mature than logistics and supply chain management conceptualisations (Dowlatshahi, 2000). Moreover, the treatment of these two concepts by the current literature is inconsistent. For example, based on extensive review of the extant literature, Ahi and Searcy $(2013,2015)$ offered 22 definitions of GSCM and 12 definitions of SSCM with respect to 7 key characteristics of business sustainability (i.e. economic, environmental, social, stakeholder, volunteer, resilience and long-term focus) and 7 key characteristics of SCM (i.e. flow, coordination, stakeholder, relationship, value, efficiency and performance focus). There are other disagreements, for example, Ahi and Searcy (2013) viewed SSCM as an extension of GSCM (excluding the integration of economic and social considerations), while Svensson (2007) asserted that SSCM incorporates the economics, ecological and societal aspects of business practice and theory. Moreover, the subject attracts different approaches, for example, in balancing the costs of a sustainable reverse logistics system with environmental and social concerns, Ramos et al., (2014) proposed a mathematical formulation and a solution approach. Finally, the manufacturing sector dominates the landscape for most SCM, SSCM and GSCM research (e.g. Holt and Ghobadian, 2009; Luthra et al., 2014; Tseng and Chiu, 2013; Zhu and Sarkis, 2004).

We now turn our attention to the retail supply chain - with a particular focus on apparel and fashion retail. In a typical retail forward supply chain the customer is at the end of the process. In the case of closed-loop supply chains, additional activities of the reverse supply chain are included, which encompass the returns process whereby the vendor has the 
intention of capturing additional value by remarketing to create and exploit additional markets for returns or overruns through redistribution (Abraham, 2011; Hvass, 2015). Alternatively, closed-loop reverse supply chains attempt to extract additional value by scrapping the product and recycling its usable parts. In the case of apparel and fashion retailers, as discussed, the latter (i.e. scrapping the product and recycling its usable parts) is not technically or economically feasible on a large scale (Hawley, 2006). Hence in the reverse supply chain of apparel and fashion retailers the key considerations are alternative business models that allow them to realise value from returned goods: a life-cycle approach for commercial returns, end-of-use returns and end-of-life returns.

Traditionally, reverse logistics is a customer service function whereby customers with warrantied or defective products could return them to the retail stores which, acting as 'gatekeepers', would then return them to their consolidation centres or suppliers (Atasu et al.,2013). Further, customers would need assurance that they could return an item and receive a refund. The handling of returns in general needs to be effectively monitored and managed because the way returns are handled is a signal to customers of how seriously corporate responsibility is taken; in addition, poor returns management results in loss of customer confidence, the potential for return process costs to escalate quickly, and the returns inventory held at the centres taking up space and incurring storage costs (Schwartz, 2000). The consolidation centre would then decide whether these goods could be used for the purpose of recapturing value as giveaways or bonus packs to customers or charitable organisations, or be returned to the manufacturer for reconditioning or refurbishment, or otherwise be destroyed or appropriately disposed of. Schwartz (2000) and Tibben-Lembke and Rogers (1998) state that every reverse logistics system should include the following functions: gatekeeping, collection, sortation and disposition.

The gatekeeping function determines which products to allow in the reverse logistics system. Collection simply means the accumulation of the products, and sortation means deciding what to do with each product. Lastly, disposition is the sending of the products to their desired destination. If the goal is to take returned products during the warranty period, then collection, storage and delivery will be important. If the goal is more environmentally related, such as reclaiming component parts, then sorting may be more important than the delivery of the parts back into the forward supply chain. Hence, there will be a different emphasis on the operations and services provided depending on the goals. 
As indicated, some of these returned apparel/fashion goods could then be distributed to secondary markets such as off-price retailers, factory and outlet stores, auction sites, online websites, charity shops, vintage shops/boutiques and consignment shops - or shops that have a combination of these elements. This constitutes the most significant aspect of apparel and fashion reverse logistics (Abraham, 2011; Hvass, 2015). The reverse logistics from the environmental perspective supports sound practices, such as recycling, reuse, remanufacturing, reconditioning and refurbishing - at various levels of products and materials use. In the case of apparel and fashion retailers, reuse, or second-life, plays the major role (Figure 1). Based on the above, the reverse logistics processes as defined by different researchers are summarised in Table 1.

[Insert Table 1 about here]

Apparel and fashion retailers traditionally have a gatekeeping, collection and disposition function. Returns and overstock flow in reverse. At the disposition function retailers face several choices (see Figure 1). One key choice is re-presenting the goods to the market through an alternative distribution and business model - creating a second life for the goods. This alternative business model in the reverse supply chain of apparel and fashion retailers has received scant attention. The second-life retailing business model concept can be extended to many other types of retail store - offering an alternative to dumping and creating waste. The focus of our research is on off-price retailers, who may source stock overruns for second-life retailing in secondary markets in developing countries. This is an area neglected by the current reverse supply chain literature.

\section{Theoretical considerations and various business models}

The foundations for our business model framework are derived from recent theoretical contributions in supply chain analysis. The resource-based view (RBV) of the firm states that development of internal capabilities and resources (Darnall et al., 2008) assists in extending the scope of flows and boundaries (Sarkis, 2012). The aim of the RBV approach is to improve resource capability through achieving a strategic fit between resources and opportunities, and obtaining added value from the effective deployment of resources. Firm resources must be organised and carefully managed, especially in planning, implementing and controlling the efficient, cost-effective flow of materials, in-process inventory, finished goods and related information from the point of origin to the point of consumption on a 
forward supply chain. Likewise, from the point of consumption to the point of origin on a reverse supply chain for the purpose of recapturing or recreating value even at the point of disposal. Going back to the point of origin is technically and economically challenging in the case of apparel and fashion retailers. The alternative is a business model that extends the life of a product - instead of disposal.

Ecological modernisation theory (Berger et al., 2001) can also be used to help identify various boundary relationships and the management of flows - particularly in its linkage to environmental and economic (boundary) performance through technology (technological boundaries) and innovation (knowledge boundaries) arising from stakeholders. In recognising this, ecological modernisation theory emphasises the possibility of a process of re-embedding economic practices with respect to their ecological dimension related to modern scientific, technological and state institutions. Therein, stakeholder theory plays a significant role in management decisions as well as providing flows and managing boundaries within the supply chain (Sangle, 2005; De Brito et al., 2008; Darnall et al., 2009). We will not delve into discussion of these specific theories, but consider these from the perspectives of individual consumers, supplier partnerships and off-price retailers within the supply-demand market opportunities of second-life retailing.

A business model describes the design or architecture of value creation and captrure: what customers want, how they want it and how the enterprise can organise itself to best meet those needs and make a profit from so doing (Teece, 2010). In essence, a business model is a conceptual view of the business, rather than a financial model. The concept of a business model has no established theoretical grounding in economics or in business studies (Teece, 2010). A business model articulates the logic, the data and other evidence that supports a value proposition for the customer, and a viable structure of revenues and costs for the enterprise delivering that value. In practice, successful business models are to some extent "shared" by multiple competitors (Teece, 2010). As demonstrated in this article, second-life retailing is shared by many vendors within a given industry - as the market is able to capture the benefit that vendors or stores will deliver to customers. In particular, a business model describes the value logic of an organisation in terms of creating and capturing customer value.

There are several business model frameworks, such as the Business Model Canvas (Osterwalder and Pigneur, 2010), the Four-Box Business Model (Johnson, 2010), the STOF 
(service, technology, organisation, finance) Model (Bouwman et al., 2008), E-Business Model Schematics (Weill and Vitale, 2001), Technology/Market Mediation (Chesbrough and Rosenbloom, 2002), Entrepreneur's Business Model (Morris et al., 2005) and e3-Value (Gordijn and Akkermans, 2001). Other sustainable business models include those of Bocken et al. (2014), Zott and Amit (2010) and Wells and Seitz (2005). While all these frameworks differ in their purpose and context, the essential dimensions are connected in a systematic manner - an overview is provided in Table 2 .

\section{[Insert Table 2 about here]}

In this paper, we use the Business Model Canvas by Osterwalder and Pigneur (2010) as the framework to conduct our case studies. The Business Model Canvas is widely used and offers a framework to analyse and understand the interfaces between different parts of a business, its environment and customers. The Business Model Canvas consists of the following nine dimensions.

1. An organisation serves one or several customer segments.

2. It seeks to solve customer problems and satisfy customer needs with value propositions.

3. Value propositions are delivered to customers through communication, distribution and sales channels.

4. Customer relationships are established and maintained with each customer segment.

5. Revenue streams result from value propositions successfully offered to customer segments.

6. Key resources are the assets required to offer and deliver the previously described elements ...

7. ... by performing a number of key activities.

8. Some activities are outsourced and some resources are acquired outside the enterprise via key partnerships.

9. The business model elements result in the cost structure.

\section{Methodology}

This paper is based on two case studies, examining the business models of two off-price Malaysian retailers. Off-price retailers play an important role in second-life retailing by reducing waste and helping to democratise consumption. They are a critical element in the 
apparel and fashion retailers' reverse supply chains. Without the off-price retailing business model most of the surplus stock and seconds would end up in landfill causing environmental damage, increasing costs and reducing margins. We have selected our cases from Malaysia because it is an emerging market where off-price retailing is less developed and more recent. Moreover, the developed world provides the backdrop to much management research and it is important to improve our nascent understanding of how organisations work in the new emerging markets.

The methodology presented in this paper is based on an approach utilising analytical review and two rounds of qualitative interviews with middle-level management comprising managers, supervisors and operating executives at both case companies, and was augmented through observations at several major outlets in major shopping malls in the city of Kuala Lumpur, Malaysia over a period between December 2014 and March 2015. The information collected was cross-checked at different outlets in different shopping malls.

The two case studies share a similar context. Hence we control for the sector, enabling us to use the Business Model Canvas to structure our data collection, offering a clear explanation of the key facets of the off-price business models of retailers operating in an emerging market. In conducting our case studies we paid particular attention to reverse logistics supply chain management and sustainability issues and the opportunity for second-life retailing offered by the off-price retailers. Our findings are summarised and detailed in the next section.

Previous research examining the alternatives to reversing to the point of origin has focused predominately on reconditioning the product. This approach is particularly useful in the case of manufacturing firms but less so in the case of apparel and fashion retailers, as discussed previously. An alternative to "reversing to the point of origin" or reconditioning, in the case of apparel and fashion retailers, is the second-life retailing business model used by off-price retailers. This facet of the reverse supply chain and off-price retailers has received little attention. Hence research presented in this paper is timely and addresses a gap in the current literature. It provides a modest but important contribution based on the emergent outcome of themes and challenges derived from the scope of the supply chain management and reverse logistics literature reviewed, pointing to entrepreneurial business models reducing waste and adding value. Further, many researchers have concentrated on developed countries - but here 
we would like to showcase specifically those off-price retailers operating in emerging markets, such as Malaysia.

\section{Findings: the second-life retailing Business Model Canvas - case examples of off-price apparel retailers and outlet stores}

In the era of global sourcing strategies, many clothing manufacturers operate in the less developed countries, exporting predominately to the developed world where retailers sell items at significantly higher prices. To maintain competiveness, many retailers frequently change their displays, mix of offerings and store designs. They offer their own brands as well as global brands. Yet the fashion industry is highly complex and competitive. In this paper we focus on two Malaysian retailers, the Factory Outlet Store (F.O.S) and the Reject Shop (RS). We selected these retailers because they are leaders in off-price retailing in Malaysia. A closer examination, however, revealed that unlike their counterparts in the developed countries - e.g. TK Maxx and Dress for Less - they operated a mixed business model combining traditional retailing with off-price retailing. They both offered their own labels as well as international brand overruns and seconds purchased at a discount as a part of their second-life retailing operations. Hence they needed to develop competencies and capabilities in two retailing areas. The two case examples of off-price retailers considered in this paper sourced stock overruns or discontinued stock from South America (Ecuador, Peru and Chile), South Asia (Bangladesh, India and Pakistan), China and Eastern Europe, where the products have been manufactured with low labour and production costs. Their existence can be explained by the ecological modernisation theory (Berger et al., 2001). These business models owe much to technology (technological boundaries) which facilitate their operations, innovation (knowledge boundaries removed by globalisation and increased connectedness among stakeholders giving rise to global brands and demand for global brands), and overlap between the traditional economic drivers and environmental and corporate responsibility drivers.

F.O.S is a chain store, currently with 50 outlets throughout Malaysia. This store sells ownlabel brands, such as Republic, Fahrenheit and Miss Cindy, (not to be mistaken with similar sounding brands popular in the UK) as well as many international brands, including Ralph Lauren, Tommy Hilfiger, Lacoste, David Beckham, Gap Kids, Levi’s, Michael Kors, Banana Republic, Zara, Gianni Valentino, Abercrombie \& Fitch, and Paul Frank as part of its secondlife business model. F.O.S is an established indigenous retailer with a presence in major 
shopping complexes; it specialises in imported stock lots and overruns, thus providing affordable quality apparel, such as graphic tees, polo tees, shirts, denim bottoms, accessories, basic wear and footwear. On the other hand, RS is a speciality store concept currently with 33 stores at many leading shopping centres across Malaysia. RS offers international label brands, such as Old Navy, Urban Pipeline, Bang Bang, and Waikiki Surf Co, again relying on overruns and seconds and its own-label brands.

In addition, both retail groups offer consigned goods, such as wallets, bags, slippers, flip flops, belts, stockings, undergarments and socks. While both retail groups combine traditional retailing with second-life retailing in their business models the mix is significantly different, with F.O.S more reliant on a second-life business model. In both cases, the range mainly consists of summer clothing, given the weather conditions of the country, but every now and then there is a new batch with warmer clothing, such as sweaters and jackets. The range of clothing offered in each of the two retailers stores is significantly different. The variation in the range of offerings is to attain greater alignment with market demand at a micro level, increasing the complexity of merchandising and supply chain management. Both retailers are synonymous with the concept of retailing internationally branded garments at a fraction of the prices charged overseas, although F.O.S has a wider range of stock. With their vast range of clothing for men, women and children these off-price retailers offer overruns, discontinued stocks, seconds, and late order cancellations. Stock is sourced from overseas factories as well as local factories. The advantage of overruns stock is that many of the brands offer relatively new styles, which would otherwise not be available. Savvy shoppers can find these fairly upto-date styles, especially for menswear, from reputable brands and occasionally designer garments. These economical products are supplemented by the retailers' own ranges for men, women and children. With their everyday, low-price philosophy they are budget friendly and have made clothing affordable to many price-conscious consumers.

Figure 2 illustrates the key elements of the business models of F.O.S and RS. The various elements of the Business Model Canvas are discussed in the following sections.

[Insert Figure 2 about here]

\subsection{Key partners}

The key partners include payment service providers, technology providers and logistics providers. They are critical to the success of both retailers, and hence significant effort is 
devoted to creating a close partnership including frequent contacts, links through automated services, and personal relationship assistants. These partners perform a key role in facilitating reverse logistics.

Payment service provider. Banks are the key payment service providers supplying payment infrastructure and credit facilities.

Technology provider for terminals at outlets/stores. Provides tangible plug-in terminals, hardware, cash registers, and automated service and checkout systems. These play a critical role in both forward and reverse supply chains. The information flow enables the retailers to make more accurate merchandising decisions reducing overstocks or stock overruns. This in turn affects purchasing and logistical decisions.

Logistics provider. Each of the retail groups has its own logistics provider. RS uses its holding company's logistic provider, whereas F.O.S uses specialist transport providers. Stock is transported on a demand basis as well as a supply basis and usually more frequently during peak season sales, with terms ranging from weekly to monthly. Operating a push system (demand) and pull system (supply) simultaneously requires significant coordination and bringing together two different sets of routines and capabilities. Both retailers use their logistics provider for both their own label and their second-life stock. Our interviews suggest that using the same logistics providers for two different types of merchandise does not cause any significant issues. Logistics planning is carried out by the head office of each retail group. In addition, both retailers use courier service delivery providers who deliver online shopping orders. The manner in which logistics operational processes are organised and executed is important as it is a key activity of these two retailers. The interviews revealed that logistics were not differentiated based on the type of merchandise, and that the lack of differentiation was not considered to be an important issue. The case study suggests that a single inward logistics system is capable of meeting the needs of both traditional and offprice merchandise.

\subsection{Key activities}

These comprise the development, maintenance and operations, including financial settlements, inventory and risk-management activities. They involve set-up and infrastructure expansion costs, maintenance and operations throughout all stores in the country. Merchandising is another key activity. Buyers were responsible for specific types of 
merchandise. Hence, in buying terms the two retail stores made a distinction between their traditional and second-life operations.

\subsection{Key resources}

The resource-based view is founded on the premise that organisation's resources and how they are combined (capabilities) are essential to its success. The key resources of these two retailers are human resources, such as product designers, buyers, store personnel and warehouse staff. A key capability is the ability to develop relationships with the local merchants as well as the financial institutions and technology vendors. The tangible resources include payment systems infrastructure, real-time data capture systems, stores location and fittings and fixtures, and marketing and promotion systems. The intangibles include trust and reputation among key stakeholders, that is, customers, suppliers, and key partners. In terms of store personnel, each store has a minimum of a supervisor, an operating executive, a storekeeper and a cashier, in addition to employing several sales personnel and a security guard depending on the size of the outlet (which can range from 5,000 square feet to 14,000 square feet in shopping malls). Store operations are led by the operating executive together with the store supervisor and storekeeper. Local product designers and local merchants (B2B) provide some of the merchandise.

As mentioned above, the forward and reverse logistics process involves the physical movement of products and returned products. The managers interviewed identified the following associated activities: (1) verifying the documentation accompanying each product and return; (2) inspecting the condition and packaging of each product and return; (3) recording any discrepancies not in accordance with the product specification and return policy; (4) assigning bar codes for products purchased and distribution and pre-disposition codes for returns; and (5) final inspection of the stocks and finalising the documentation.

Clearly, the above forward and reverse logistics are highly dependent upon the efficiency of human resources, though it may appear that the information technology providers are the key partners. The forward logistics capability was identified by managers of both retail groups as an important competency for both own-brand and second-life merchandise. It was also pointed out that second-life merchandise offered a greater challenge because of the remoteness of the suppliers, the transportation distance and the complexity of international logistics. Furthermore, buyers had little control over second-life merchandise, in that they 
could not pre-specify, and their decision was based on the suitability of stock available for their local market. The opportunity for repeat orders was rare.

We also discovered that reverse logistics, irrespective of whether merchandise was own brand or second life, presented a greater challenge. This is because the priority, understandably, is getting the product out to the customers, rather than dealing with returns "coming back". Prompt handling of returns is often an issue according to the managers interviewed. This is because the combination of processes that form reverse logistics competencies is complex and there is a lack of capabilities, a limitation that is faced especially by B2B merchants as compared to $\mathrm{B} 2 \mathrm{C}$, which are relatively easier to process. The $\mathrm{RBV}$ explains many of the practical issues highlighted by our respondents.

\subsection{Customer segments}

$B 2 B$ merchants. The teams of managers in both retail groups co-ordinate activities with their own respective suppliers, plan and monitor production (which could be derived from sales forecasts, actual orders or planned orders) and resolve any operational difficulties, if any. The completion times of delivery operations at the various store locations are also planned in each cycle. The strategic objective of both retailers is to maximise margins and earn a reasonable profit. To this end own labels were sourced as much as possible locally. Local sourcing offered a number of important advantages including shorter merchandise delivery lead time, reliability, closer relationship, simpler logistics and lower logistics costs. This sourcing strategy offered both retailers important competitive advantages: lower costs; improved margins; faster reaction to changes in taste; and lower stock overruns. The local purchasing strategy had an important environmental consequence of reducing the two retailers' carbon footprints. The model used here is based on purchasing at the lowest possible price; hence there are a variety of suppliers to ensure competition and resultant low prices.

Offshore sourcing of supplies occurred predominately in relation to the second-life retailing business model. The offshore sourcing incurred some hidden costs including procurement, time spent on acquisition and monitoring progress, and the possibility of lost sales due to late delivery or incomplete delivery (e.g. wrong size ratios, colour mix, style mix). Such hidden costs are less of an issue when sourcing locally. Returning to the off-shore procurement costs, these included airfares, hotel bills, telephone calls and subsistence payments. These can be significant, although they were categorised as overhead costs masking the true costs of off- 
shore procurement. Interestingly, in some cases, the cost of procurement exceeded the value of the final invoice. On the other hand, these stocks were mostly the international overruns, discounted stock or lost sales overseas that are sourced for second-life retailing. Although we were unable to ascertain the environmental impact of long distance procurement prevalent in the case of second-life merchandises such as carbon footprint, we estimate this not to be insignificant and this has to be set against the environmental benefit of second-life retailing. Based on our discussion and assuming the second-life merchandising would have ended in a landfill site we estimate a significant positive environmental impact.

Local sources. Most stock is sourced locally onshore with new product designs and occasionally recycled textile sources. They are closer to market and hence any delay in production may not necessarily result in late delivery in contrast to offshore suppliers that usually take at least four weeks for delivery. The recycled textile is sourced from various local suppliers through the supply chain manufacturers to improve resource productivity and reduce costs through the reuse and recovery of materials. Along these lines, the fashion design is a creative process of enabling these materials to be reused thus reducing operating costs in the supply chain and generating more revenue, and hence we see the lower price of apparels. Thus both F.O.S and RS tend to source more locally than offshore, making bulk purchases on a timely and regular basis for their own-label brands. They also source locally for design creation services in which they may own (fully or partially) some of these suppliers of contract garment manufacturers and warehouse providers. These local supply contractors are aware that competitive markets and negotiations are made from time to time, except for those international overruns or discounted stocks. The local supply contractors are mainly closed-loop supply based on direct order service contracts and are credit-based as they are viewed as effective. Some of the international brands are retagged or relabelled, or even unlabelled, due to the quality of manufacture or product faults. Local onshore suppliers are short term, competitive, low priced and low quality, but inevitably with reasonable levels of trust between the retailers and suppliers. Accordingly, the number of suppliers is small to ensure dependency and dedication. Effective supplier relationships are fostered as well as planning of merchandise distribution. For example, to drive sales, special packaging to promote products and repackaging any unsold inventories for sale in the following season is undertaken for seasonal products such as winter apparel that are sold to these off-price retailers. This means that they are sold on the secondary market here immediately following the prime selling season overseas for international brands. 
Own-label stock is built around vendor-managed inventory (VMI), which offers both retailers system efficiency in merchandise planning and synchronised production scheduling, enabling them to order stock as required in order to best meet customers' needs. The system minimises retailers' stockholding costs and potential for surplus stocks. In turn, the suppliers, via collaborative planning offered by both retailers, are able to manage production flows more efficiently and to meet the retailers' demands. To optimise the flow of information and merchandise, retailers employ technology such as barcodes and electronic point of sale (EPoS), which transmits information on size, style and colour of products back to the head office. However, most often, once the stock is sold, then it has gone for good and the retailers move on to the next design, rather than replenish stock. Supply chain management has been created internally and externally to support and supply products effectively to customers. Notably, the responsibility has been shifted to the suppliers in the pre-retailing services (labelling, ticketing, steaming, pressing and packaging for store-ready display), hence this lowers the inventory risks, processing and stockholding costs and services. Distribution of stock and inventory levels are determined at head offices with reduced stock-outs in mind, and some ordered stock is also stored at the various outlets prior to goods being sold.

Decisions concerning what activities and operations are appropriate for the second-life retailing in the reverse logistics flow are based on the operational goal of the retailers in reverse logistics. Economic value recovery is obtained through the second-life retailing where the reverse logistics network consolidates, inspects and sorts items as needed and then allocates and transports them for various recovery options. The responsibility for collecting and recovery of second-life retailing opportunities may be taken by manufacturers, thirdparty logistics, or retailers as shown in Figures 1 and 2. A high level of coordination and collaboration among these parties is imperative in the second-life retailing business model. Clear and effective cooperation mechanisms and well-defined contractual agreement on terms and conditions between the entities are prevalent.

B2C customers. Customers tend to visit stores frequently to view and purchase fast-moving fashion goods. RS predominately targets fashion-conscious younger people. Its success is built on its low-price philosophy. The target niche and the low price point are reflected in the range of its second-life brands as highlighted previously. F.O.S targets a broader age range and value is reflected in offerings at two different price points (low and medium) as opposed to RS's single price point (low). F.O.S's low price point merchandise are mainly own label, 
while second-life represents the medium price point where top international brands are offered at substantial discounts. This is an interesting point to note and contrasts with the approach of RS and more importantly with off-price retailers operating in developed countries.

In the case of both retail groups, the emphasis on fashion means that own brand fashion lines are not replenished and purchases are made in relatively small quantities which are easily disposable. When it's gone, it's gone and that attracts customers into stores for more current trends. The fashion lines are for immediate wear and are not built to last, tempting customers to repurchase within a shorter timeframe for more clothing given its affordability. In addition, the store outlets save time operationally by taking delivery of floor-ready merchandise - that is merchandise with a bar code and pricing information. Key merchandising decisions such as the design and style of garments along with colour ranges are made centrally. Sourcing locally and using VMI means that decisions on colour can be made much closer to the time goods are required in the stores, reducing stockholding and the risk of bad decisions. The use of technology enables management to base merchandising decisions on up-to-date sales figures or on best-selling lines at various stores. Moreover, the technology provides connectivity and visibility to suppliers. The store manager/sales staff at store outlets can also improve customer service by ascertaining where garments are in the supply chain and being able to process customer orders based on this information. This is similar to the quick response strategy in UK fashion retailers (Birtwistle et al., 2003). This shortens the distribution cycle and reduces handling costs while increasing the accuracy of delivery and improving in-stock situations of own brands.

The situation with second-life apparels is somewhat different. The procurement is based on availability rather than pre-specification. Both retailers purchase what is available unlike their own brands which are pre-specified. The key decision that buyers make is the fit between available second-life stocks and local consumer tastes. If the fit exists then the second-life stock is purchased. The availability of real-time sales information and popularity of merchandise lines are helpful to buyers' decision making.

F.O.S offers clothing at different key price points including second-life branded apparel at a significant discount. Hence, F.O.S has a wider customer base and targets a broader age range compared to RS, whose customers tend to be younger and more interested in trendy T-shirts designed, manufactured and sourced locally as well as some lesser known overseas brands. 
In view of this, the supply chain and reverse logistics is complex and includes a diverse range of local and international suppliers. The complexity of the supply line is such that if it is not effectively managed it can have significant detrimental impact on both retailers' bottom line. The reverse logistics of second-life vendors is part of F.O.S and RS's forward supply chains. The second-life merchandise is more important to F.O.S, enabling it to broaden its merchandise range and price points making its proposition attractive to a broad range of price conscious consumers. It is also important to RS helping to attract customers through its stores. The business model built around second-life retailing in essence complements the traditional retailing business model. In short, the second-life retail business model contributes to increased revenue, reputation, trust, and improved customer service.

Purchased goods can be returned up to three days after purchase. They have to be in good condition in order to be exchanged for other products. These returned goods are then redisplayed at the store for resale after inventory checks. If they are no longer fit for display, then they are discarded.

In our observations, customers of F.O.S are from various different age groups, while those of $\mathrm{RS}$ are younger in age thus demonstrating the differentiation in its $\mathrm{B} 2 \mathrm{C}$ relationship. This is reflected in the purchasing ability of its customers and its strata of customers who tend to buy more value-for-money apparel, which arguably also impacts on both revenue streams and profitability. This further emphasises the supply chain benefits that can be gained by making decisions on design and style of garments along with colour ranges closer to the demand of young age groups and enabling the supply chain partners to identify which garment lines are the best sellers. In addition, from the retailer perspective, accurate sales and stock data allow the management of stock deliveries to be more effective by liaising with merchandisers as well as influencing future orders.

\subsection{Customer relationships}

Unlike RS, F.O.S operates a membership card system giving members certain privileges, such as loyalty purchases. F.O.S offers a greater service level to its customers as, for example, customers have access to personal sales assistants employed at the outlets thus creating a superior service encounter.

Stocks may differ from one outlet to the other to encourage the sense of differentiation. This is dependent on the popularity of certain types of apparel which can be more saleable in some 
outlets but not necessarily so in some other locations in the country. Stock is also frequently arranged and rearranged in the stores to generate the impression of new stock arrivals.

Registration for membership is also made available to customers at F.O.S to ensure business sustainability via its loyalty promotion, while such a facility is absent at RS. Service provision at both retailers is adequate and satisfactory, and given the background of customers, complaints are not envisaged, and any returns are accepted within a stipulated time period after purchase, normally three days.

\subsection{Channels}

Web. F.O.S utilises social networking sites, such as Facebook, Twitter and Instagram, to further promote its stores and merchandise. The F.O.S rewards programme was recently introduced based on a loyalty card, which allows the accumulation of points and a $10 \%$ discount. In addition, a RM10 rebate (discount) voucher is given on accumulation of every 500 points, and the scheme offers special birthday discounts, exclusive event invitations to new store openings, members-only sales, special offers, exclusive deals, warehouse sales and other special events to drive sales and customer loyalty. F.O.S offers a greater variety of merchandise compared to RS and is also more competitive. Such incentives to drive sales and customer loyalty have a positive impact on its forward distribution activities. It results in faster speed to market, and provides inbound and outbound transportation support in the supply chain activities in the network of facilities. In turn, this benefits customers, suppliers, stores, distribution centres and the financials of the company.

Advertising and promotions. Both retailers use conventional mass media (above-the-line advertising), pamphlets (below-the-line advertising) and, increasingly, digital media as well as in-store promotions and warehouse sales to promote their stores and merchandise. The forward supply chain is used to dispose of left-over stock. Strategies used include in-store promotions on a seasonal basis to clear stock that has been in the store for over a year. Stock is also moved from one outlet to another to improve the likelihood of it being sold or cleared. Stock is also sold more cheaply in seasonal warehouse sales, which are organised in smaller shopping malls where large units can be rented relatively cheaply for two to three days to house such sales. When these stocks are not sold, they are redistributed back to the stores for the purpose of recapturing value, whilst defective items are disposed of.

\subsection{Costs structure}


Costs result from the set-up and operation in infrastructure and expansion of the retailers. Furthermore, costs also occur from tangibles and intangibles from partners, merchants, and customers in addition to staff employment and promotion.

The forward and reverse logistics process can cause loss in profits due to external liabilities that could have an enormous impact on their business if not effectively managed. In normal circumstances, reverse logistics costs are less than 5\% of total supply chain costs. The increased risks and processing costs require the retailers and manufacturers in the supply chain to examine their existing reverse logistics processes to ensure they have full control over the process and subsequently product disposition. Reverse logistics happens in response to an action of a customer or supply chain actor and as such is difficult to anticipate or comprehensively plan for by the retailer. Often the retailers tend to focus on ad-hoc transportation and storage of returned products, and when this happens the retailers lack the efficiency of balancing cost-efficiency (minimal transport expenses and returns inventory) with market proximity and availability of supply chain cooperation and relationship management.

Handling returns properly and tracking all activities are critical to the maximisation of efficiency. Returns policies establish guidelines that govern when a product is to be returned and under what conditions it will be accepted, alongside establishing an acceptable level of customer service with a view to protecting the goodwill of the company. Accurate knowledge of what is returned makes it easier to evaluate returned stocks for possible re-distribution through second-life sales channels.

Second-life retailing has an important international dimension. Through the reverse supply chain, second-life retailing provides a channel from international brand suppliers to the secondary off-retailers markets for seasonal products, providing recovery value for manufacturers, as well as closed loop supply of local manufacturers. In this respect, the returns for second-life retailing entails a creative approach of commercial returns whereby the returns are for immediate demand at another market location. Commercial returns occur in the normal (primary) sales phase or shortly after the seasons. There are other beneficial aspects to disposing of products, especially recalled or end-of-life products, such as avoiding excess inventory carrying costs, minimising taxes and insurance and managing staff in the forward and reverse supply chain logistics. 


\subsection{Revenue streams}

The source of revenue is dependent on purchases offered at stores and online by the retailers to the customers. The key partners of retailers also generate revenue from their bank facility of card application terminals that are transaction-dependent. In the reverse supply chain logistics, revenue can be gained by offering second-life merchandise through marketing in secondary markets. A source of additional revenue is the flow of returned products that in turn can bring efficiencies in production and logistics and distribution costs, by combining the forward logistics product drop-off with the reverse logistics pick-up. Merging forward and reverse flows efficiently leads to greater synergies between them. As such it is important to optimise forward logistics. Often a reverse logistics process is set up in response to hidden mistakes in the forward supply chain such as inadequate packaging, inferior materials and poor delivery performance. Thus, it is critically important to consider reverse logistics budgeting.

\subsection{Value proposition}

We highlight the value proposition in terms of value consumption, value renewal and price level attributes in the creative approach of capturing the benefits of forward and reverse supply chain process. The value proposition of both F.O.S and RS as traditional retailers is fashion at an affordable price. The same proposition applies to the second-life retailing proposition of RS. This is reflected in the brands offered. The value proposition of secondlife retailing of F.O.S is slightly different offering well known international brands at a fraction of their original price but at a significantly higher price than their own brand. This enables the F.O.S to operate at two key price points (low and medium), and hence to widen its appeal to a broader age range and disposable income. The trendy designs are aimed at lower income and younger adults who have just entered the workforce. Offers and discounts are available throughout all seasons, which in turn generate increased sales. Where prices are kept low, the operational costs also decrease. Customer data are collected and supplementary discounts and offers are available, thus in the long run customer retention is possible with a product returns facility within the stipulated period.

F.O.S is larger (it has more stores), attracts a broader customer base, has its stores in more attractive locations and has greater estimated turnover. Both retailers offer a combination of 
their own brands and second-life international brands. The second-life retailing of F.O.S is more extensive than RS and this account for the difference between the two groups.

In its value proposition, F.O.S has a major impact on market offerings of off-price retailing. The value proposition refers to how items of value, in this case apparel as well as complementary value-added services are packaged and offered to fulfil customer needs. The firm's products and services together represent value for a specific customer segment. It describes the way a firm differentiates itself from its competitors and is the reason why customers buy from a certain firm like F.O.S and not from another. With more outlets, better marketing strategies, and reward point systems, F.O.S provides its assumed value to the customers with off-price goods of international brands through its reverse supply chain process which creates a value renewal utility. The reverse supply chain creates new breakthrough markets and the differentiation is captured in the price level attribute of the value proposition.

The off-price retailing of apparel has created a new channel of value consumption. The best known and traditional phase of value life cycle is the value derived from consumption. This is the value that comes from the actual use of a product/services and is the dominant part of the value proposition. It is even more interesting to know that the value consumption has an added element of value renewal whereby customer utility is extended through such creation of secondary markets, when value consumption at primary markets diminishes.

\section{Concluding remarks and implications}

Green supply chain, sustainable supply chain and reverse supply chain are subjects of interest to researchers and policy makers. The increasing interest is due to many factors including consumers' increasing awareness and interest, NGOs, regulations, and digital technology. Manufacturing provides the backdrop to much of the research. Yet in developing countries, service industries account for the major share of GDP and in emerging markets services are increasing their share of GDP. Paucity of research examining reverse supply in services is a significant gap. Yet researching services is complex because of the heterogeneity not only between service sectors, but within a given service sector.

In this paper we have focused on apparel and fashion retailers because forward and reverse supply chain activities are critical to their success and they are also economically important in both developed and emerging economies. The prevalent concept in the reverse supply chain 
of manufacturing is return to origin - to either refurbish or extract usable components for further use. As we have noted, this is less attractive in apparel and fashion retailing. On the other hand, reverse supply chain of apparel and fashion retailers offer the opportunity for alternative entrepreneurial business models.

Our aim was to examine entrepreneurial business models arising from the reverse supply chain of apparel/fashion retailers. One such business model is off-price retailing. In the USA, off-price retailing came to fore in the late 1970s. The concept reached Europe in the 1980s. Off-price retailing is a business model predicated on selling excess inventory that is not sold by speciality retailers or department store, that is to say seconds and production overruns sold at $20 \%$ to $60 \%$ discount. It reduces waste, creates value, and democratises consumption. The business model has diffused to emerging markets in recent years.

This paper examines the business model of two off-price retailers operating in Malaysia using the business canvas model as a framework to guide data collection. This approach - mapping reverse supply chain approaches against the specific characteristics included in the framework can help us to analyse, illustrate and inform the future design of service business models. Additionally, defining those dimensions in the retailers' value proposition to customers, and partners, provides an overview of the business logic of a service in its collaboration and integration. The retailers deal with extending the life cycle of merchandise from a cluster of services (retailers), that goes beyond the traditional forward supply chain, extending service offerings via remarketing of environmentally friendly disposal into secondary niche markets.

The Business Model Canvas offers a tool that helps illustrate the concept and adds value to the co-creation of retail businesses, reducing waste and enhancing sustainability through goods being sold further at secondary markets. Here, we have demonstrated the applicability of an approach to widening the perspective of retailing to second-life channels, and thus to improving environmental sustainability through waste reduction. In addition, local merchants and product designers are also afforded new opportunities by becoming key partners and key resources in the business model. The second-life retailing approach enables them to demonstrate their talents and skills in pooling their resources in the retail business.

Several implications emerge from this research. Firstly, for theory, the above case examples add to our nascent knowledge of alternative approaches to reverse supply chain management 
within the retail sector. As this paper demonstrates, retail reverse supply chain offers secondlife retailing - a business model enhancing sustainability, reducing waste and adding value. Practically, the products could be remarketed to re-create and exploit additional markets for returns or overruns through redistribution. Thus it is important to note that in this reverse and closed-loop supply chains where making profit and minimising cost are crucial in addition to meeting environmental targets, overruns do not go to waste in one country, but find their way to use/consumption in another market. In 'creating value from waste', this sustainable business model archetype (Bocken et al., 2014) offers a valuable alternative to 'waste', by turning otherwise normal waste streams into useful and valuable input for value creation and delivery, and making better use of potentially under-utilised operational/logistics capacity. Economic and environmental costs are reduced through reusing goods and turning waste into value by bringing these overruns into secondary markets. This brings about a positive contribution to society and the environment through reduced waste.

Secondly, the apparel industry of off-price retailers is impacted by the reverse logistics process where they would be expected to develop the most efficient returns processes, however their efficiency and effectiveness to develop best practices is still limited where they are struggling to make cost-savings in their distributive operations. As such, companies use a business model that allows them to realise value out of a life-cycle approach for commercial returns, overruns, end-of-use returns or even end-of-life returns.

Finally, this alternative business model serves the dual purpose of both business and environmental sustainability by avoiding the generation of large amounts of waste in landfill sites and maximising efficiency by enhancing value proposition, value creation and delivery, and value capture. This will inevitably impact upon society's awareness of reducing waste and promote second-life retailing as high-value recovery and reconditioning of goods in reverse supply chains. This is consistent with the research literature of both reverse supply chain and sustainability.

There is further substantial future work needed to better understand the second life retailing business model and its contribution to sustainability. The various boundaries of many levels of supply chain analysis can be interpreted by different stakeholders mapped by boundaries, responsibilities and industrial practices of business economic dimensions (Sarkis, 2012). Collaborations between supply chain partners may help to realise financially beneficial and innovative options. Thus, the dynamics of these inter-firm relationships may offer insights 
into the potential of second-life retailing in reverse logistics in creating new markets and profitable operations. An understanding of the implications in terms of the markets they serve and the markets that they procure their used products from poses interesting questions for future research.

\section{References}

Abbasi, M. and Nilsson, F. (2012), "Themes and challenges in making supply chains environmentally sustainable", Supply Chain Management: An International Journal, Vol. 17 No. 5, pp. 517-30.

Abraham, N. (2011), "The apparel aftermarket in India: a case study focusing on reverse logistics”, Journal of Fashion Marketing and Management: An International Journal, Vol. 15, No. 2, pp. 211-227.

Ahi, P. and Searcy, C. (2013), "A comparative literature analysis of definitions for green and sustainable supply chain management", Journal of Cleaner Production, Vol. 52 No. 1, pp. 329-41.

Ahi, P. and Searcy, C. (2015), “An analysis of metrics used to measure performance in green and sustainable supply chains", Journal of Cleaner Production, Vol. 86 No.1, pp. $360-77$.

Ashby, A., Leat, M. and Hudson-Smith, M. (2012), "Making connections: a review of supply chain management and sustainability literature", Supply Chain Management: An International Journal, Vol. 17 No. 5, pp. 497-516.

Atasu, A., Toktay, L. B. and Van Wasenhove, L. N. (2013), "How collection cost structure drives a manufacturer's reverse channel choice", Production and Operations Management, Vol. 22 No. 5, pp. 1089-102.

Berger, G., Flynn, A., Hines, F. and Johns, R. (2001), "Ecological modernization as a basis for environmental policy: current environmental discourse and policy and the implications on environmental supply chain management", Innovation: The European Journal of Social Science Research, Vol. 14 No. 1, pp. 55-72. 
Birtwistle, G., Siddiqui, N. and Fiorito, S. S. (2003), “Quick response: perceptions of UK fashion retailers", International Journal of Retail \& Distribution Management, Vol. 31 No. 2, pp. 118-28.

Bocken, N. M. P., Short, S. W., Rana, P. and Evans, S. (2014), “A literature and practice review to develop sustainable business model archetypes", Journal of Cleaner Production, Vol. 65, pp. 42-56.

Bouwman, H., De Vos, H. and Haaker, T. (2008), Mobile Service Innovation and Business Models, Springer, Berlin and Heidelberg.

Brace-Govan, J. and Binay, I. (2010), "Consumption of disposed goods for moral identities: a nexus of organization, place, things and consumers", Journal of Consumer Behaviour, Vol. 9 No. 1, pp. 69-82.

Carter, R. C. and Easton, P. I. (2011), "Sustainable supply chain management: evolution and future directions", International Journal of Physical Distribution \& Logistics Management, Vol. 41 No. 1, pp. 46-62.

Chesbrough, H. and Rosenbloom, R. S. (2002), "The role of the business model in capturing value from innovation: evidence from Xerox Corporation's technology spin-off companies", Industrial and Corporate Change, Vol. 11 No. 3, pp. 529-55.

Chuang, C. H., Wang, C. X. and Zhao, Y. (2014), "Closed-loop supply chain models for a high-tech product under alternative reverse channel and collection cost structures", International Journal of Production Economics, Vol. 156, pp. 108-23.

Corbett, C. J. and Kleindorfer, P. R. (2003), "Environmental management and operations management: introduction to the third special issue", Production and Operations Management, Vol. 12 No. 3, pp. 287-89.

Darnall, N., Jolley, G. J. and Handfield, R. (2008), "Environmental management systems and green supply chain management: complements for sustainability?” Business Strategy and the Environment, Vol. 17 No. 1, pp. 30-45. 
Darnall, N., Seol, I. and Sarkis, J. (2009), "Perceived stakeholder influences and organizations' use of environmental audits", Accounting, Organizations and Society, Vol. 34 No. 2, pp. 170-87.

De Brito, M. P., Carbone, V. and Blanquart, C. M. (2008), “Towards a sustainable fashion retail supply chain in Europe: organisation and performance", International Journal of Production Economics, Vol. 114 No. 2, pp. 534-53.

Dowlatshahi, S. (2000), "Developing a theory of reverse logistics", Interfaces, Vol. 30 No. 3, pp. 143-55.

Emmelhainz, M. A. and Adams, R. J. (1999), “The apparel industry response to "sweatshop" concerns: a review and analysis of codes of conduct", Journal of Supply Chain Management, Vol.35, No.3, pp. 51-7.

Fawcett, S. E., Magnan, G. M. and McCarter, M. W. (2008a), "A three-stage implementation model for supply chain collaboration”, Journal of Business Logistics, Vol. 29 No. 1, pp. 93-112.

Fawcett, S. E., Magnan, G. M. and McCarter, M. W. (2008b), "Supply chain alliances and social dilemmas: bridging the barriers that impede collaboration", International Journal of Procurement Management, Vol. 1 No. 3, pp. 318-40.

Ghobadian, A., Money, K., \& Hillenbrand, C. (2015). Corporate Responsibility Research: Past-Present-Future. Group \& Organization Management, Vol. 40 No. 3, pp. 271294.

Gordijn J. and Akkermans, H. (2001), "Designing and evaluating e-business models", IEEE Intelligent Systems, Vol. 16 No. 4, pp. 11-17.

Guide Jr., V. D. R., Harrison, T. P. and Van Wassenhove, L. N. (2003), "The challenge of closed-loop supply chains', Interfaces, Vol. 33 No. 6, pp. 3-6.

Guidini, R. (1996), “An introduction to reverse logistics for environmental management: a new system to support sustainability and profitability", Total Quality Environmental Management, Vol. 5 No. 3, pp. 81-7. 
Handfield, R. B. and Nichols, E. L. (1999), Introduction to Supply Chain Management, Prentice Hall, Inc., Upper Saddle River, NJ.

Harris, G. (2013), "Bangladeshi factory owners charged in fire that killed 112", The New York Times, 22 December, available at: www.nytimes.com/2013/12/23/world/asia/bangladeshi-factory-owners-charged-infatal-fire.html (accessed 15 January 2015).

Hawley, J. M. (2006), “Textile recycling: a system perspective”, In Recycling in textiles (Ed, Wang, Y.) Woodhead Publishing Limited, Abington, UK, pp. 7-24.

Hillenbrand, C., Money, K. and Ghobadian, A. (2013), "Unpacking the mechanism by which corporate responsibility impacts stakeholder relationships", British Journal of Management, Vol. 24 No. 1, pp. 127-46.

Holt, D. and Ghobadian, A. (2009), “An empirical study of green supply chain management practices amongst UK manufacturers", Journal of Manufacturing Technology Management, Vol. 20 No. 7, pp. 933-56.

Hu, G. and Bidanda, B. (2009), "Modeling sustainable product lifecycle decision support systems", International Journal of Production Economics, Vol. 122, No. 1, pp. 366375.

Hvass, K. K. (2015), “Business Model Innovation through Second Hand Retailing: A Fashion Industry Case”, Journal of Corporate Citizenship, Vol. 2015, No. 57, pp. 11-32.

Isaksson, R., Johansson, P. and Fischer, K. (2010), "Detecting supply chain innovation potential for sustainable development”, Journal of Business Ethics, Vol. 97, pp. 425442.

Jain, V., Wadhwa, S. and Deskmukh, S.G. (2009), "Select supplier-related issues in modelling a dynamic supply chain: potential, challenges and direction for future research", International Journal of Production Research, Vol. 47 No. 11, pp. 301339.

Johnson, M. W. (2010), Seizing the White Space: Business Model Innovation for Growth and Renewal, Harvard Business Press, Boston, MA. 
Klausner, M. and Hendrickson, C. (2000), "Reverse-logistics strategy for product take-back", Interfaces, Vol. 30 No. 3, pp. 156-65.

Kleindorfer, P. R., Singhal, K. and van Wassenhove, L. N. (2005), "Sustainable operations management", Production and Operations Management, Vol. 14 No. 4, pp. 482-92.

Kumar, V., Holt, D., Ghobadian, A., and Garza-Reyes, J. A. (2014), "Developing green supply chain management taxonomy-based decision support system". International Journal of Production Research, Published online 21 May 2014.

Lau, K. H. (2011), "Benchmarking green logistics performance with a composite index”, Benchmarking, Vol. 18 No. 6, pp. 873-96.

Lee, J. J., O'Callaghan P. and Alien, D. (1995), “Critical review of life cycle analysis and assessment techniques and their application to commercial activities", Resources, Conservation and Recycling, Vol. 13 No. 1, pp. 37-56.

Linton, J. D., Klassen, R. and Jayaraman, V. (2007), "Sustainable supply chains: an introduction", Journal of Operations Management, Vol. 25 No. 6, pp. 1075-82.

Luthra, S., Garg, D. and Haleem, A. (2014), "Green supply chain management: implementation and performance - a literature review and some issues", Journal of Advances in Management Research, Vol.11 No.1, pp. 20-46.

Meade L. and Sarkis, J. (2002), “A conceptual model for selecting and evaluating third-party reverse logistics providers", Supply Chain Management: An International Journal, Vol. 7 No. 5, pp. 283-95.

Meyer, H. (1999), “Many happy returns”, Journal of Business Strategy, Vol. 80 No. 7, pp. 27-31.

Mohr, L. A. and Webb, D. J. (2005), "The effects of corporate social responsibility and price on consumer responses", Journal of Consumer Affairs, Vol. 39 No. 1, pp. 121-47.

Morris, M., Schindehutte, M. and Allen, J. (2005), “The entrepreneur's business model: toward a unified perspective", Journal of Business Research, Vol. 58 No. 6, pp. 72635. 
Nagurney, A. and Toyasaki, F. (2005), "Reverse supply chain management and electronic waste recycling: a multitiered network equilibrium framework for e-cycling", Transportation Research Part E: Logistics and Transportation Review, Vol. 41 No. 1, pp. 1-28.

Osterwalder, A. and Pigneur, Y. (2010), Business Model Generation: A Handbook for Visionaries, Game Changers and Challengers, John Wiley \& Sons, Hoboken, NJ.

Ramos, T. R. P., Gomes, M. I. and Barbosa-Póvoa, A. P. (2014), "Planning a sustainable reverse logistics system: balancing costs with environmental and social concerns", Omega, Vol. 48, pp. 60-74.

Sangle, S. (2005), "Redefining environmental management system boundaries through stakeholder management across product life-cycle", International Journal of Environment and Sustainable Development, Vol. 4 No. 2, pp. 193-207.

Sarkis, J. (2012), “A boundaries and flows perspective of green supply chain management”, Supply Chain Management: An International Journal, Vol. 17 No. 2, pp. 202-16.

Sarkis, J., Zhu, Q. and Lai, K.-H. (2011), “An organizational theoretic review of green supply chain management literature", International Journal of Production Economics, Vol. 130 No. 1, pp. 1-15.

Savaskan, C., Bhattacharya, S. and Van Wassenhove, L. N. (2004), “Closed loop supply chain models with product remanufacturing", Management Science, Vol. 50 No. 2, pp. 239-52.

Schwartz, B. (2000), "Reverse logistics strengthens supply chain", Transportation and Distribution, Vol. 41 No. 5, pp. 95-100.

Seuring, S. and Müller, M. (2008), "From a literature review to a conceptual framework for sustainable supply chain management”, Journal of Cleaner Production, Vol. 16 No. 15 , pp. 1699-710.

Simpson, D. (2010), "Use of supply relationships to recycle secondary materials", International Journal of Production Research, Vol. 48 No. 1, pp. 227-49. 
Steurer, R., Martinuzzi, A. and Margula, S. (2012), "Public policies on CSR in Europe: themes, instruments, and regional differences", Corporate Social Responsibility and Environmental Management, Vol. 19 No. 4, pp. 206-27.

Svensson, G. (2007), “Aspects of sustainable SCM: conceptual framework and empirical example", Supply Chain Management: An International Journal, Vol. 12 No. 4, pp. 262-6.

Sweeney, L. and Coughlan, J. (2008), "Do different industries report corporate social responsibility differently? An investigation through the lens of stakeholder theory", Journal of Marketing Communications, Vol. 14 No. 2, pp. 113-24.

Teece, D. J. (1996), "Firm organization, industrial structure, and technological innovation", Journal of Economic Behavior \& Organization, Vol. 31 No. 2, pp. 193-224.

Teece, D. J. (2010), “Business models, business strategy and innovation”, Long Range Planning, Vol. 43 No. 2/3, pp. 172-94.

Tibben-Lembke, R. S. and Rogers, D. S. (1998), "The impact of reverse logistics on total cost of ownership", Journal of Marketing Theory and Practice, Vol. 6 No. 4, pp. 51-60.

Tseng, M.-L. and Chiu, A. S. F. (2013), "Evaluating firm's green supply chain management in linguistic preferences", Journal of Cleaner Production, Vol. 40, No. 0, pp. 22-31.

Utting, P. (2005), "Corporate responsibility and the movement of business", Development in Practice, Vol. 14 No. 3/4, pp. 375-88.

WCED (1987). Our Common Future. Oxford University Press, Oxford, UK.

Weill, P. and Vitale, M. R. (2001), Place to Space: Migrating to eBusiness Models, Harvard Business School Publishing Corporation, USA.

Wells, P. and Seitz, M. (2005), "Business models and closed-loop supply chains: a typology”, Supply Chain Management: An International Journal, Vol. 10 No. 4, pp. 249-51.

Zhou, F. (2009), "Study on the Implementation of Green Supply Chain Management in Textile Enterprises", Journal of Sustainable Development, Vol. 2, No. 1, pp. 75-79. 
Zhu, Q. and Sarkis, J. (2004), "Relationships between operational practices and performance among early adopters of green supply chain management practices in Chinese manufacturing enterprises”, Journal of Operations Management, Vol. 22, No. 3, pp. $265-289$.

Zott, C. and Amit, R. (2010), "Business model design: an activity system perspective", Long Range Plan, Vol. 43, No. 2/3, pp. 216-26.

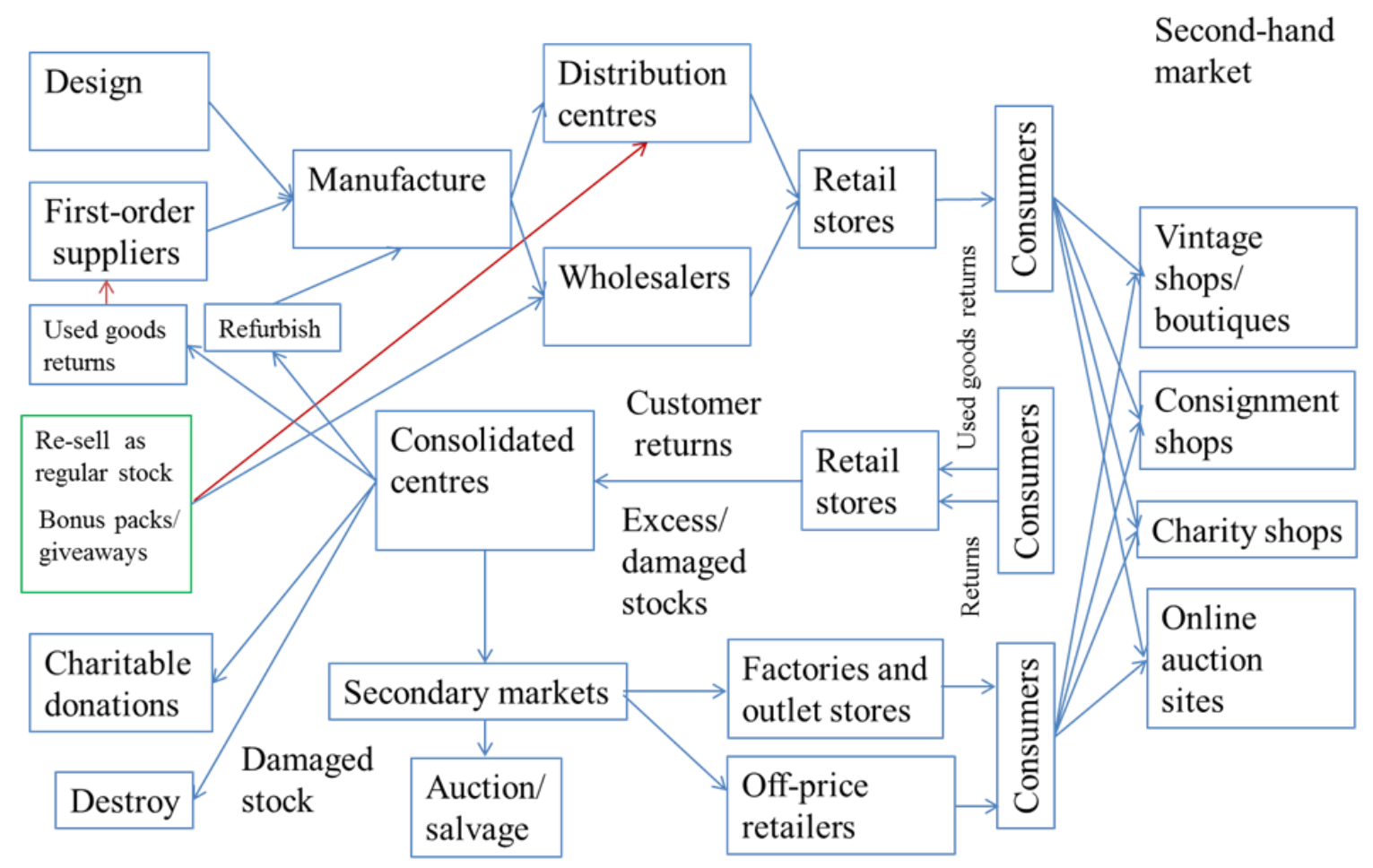

Figure 1. Typical retail forward and reverse supply chains

Table 1. The reverse logistics process 


\begin{tabular}{|l|l|}
\hline Key elements of the process & Reference \\
\hline Gatekeeping, collection, sortation and disposition & Schwartz (2000) \\
\hline $\begin{array}{l}\text { Cost/benefit analysis, transportation, warehousing, supply } \\
\text { management, remanufacturing/recycling and packaging }\end{array}$ & $\begin{array}{l}\text { Tibben-Lembke and Rogers } \\
(1998)\end{array}$ \\
\hline $\begin{array}{l}\text { Managing product returns, real-time inventory and workflow; } \\
\text { tracking warranties; ordering and exchanging parts; } \\
\text { collaborating with suppliers; analysing data; performing } \\
\text { repairs; remanufacturing; recycling; and customer notification }\end{array}$ & Dowlatshahi (2000) \\
\hline
\end{tabular}


Table 2. Summary and overview of business models

\begin{tabular}{|c|c|}
\hline Models (reference) & Dimensions/domains \\
\hline $\begin{array}{l}\text { Four-Box Business Model } \\
\text { (Johnson, 2010) }\end{array}$ & $\begin{array}{ll}\text { - } & \text { Customer value proposition } \\
\text { - } & \text { Profit formula - revenue model, cost structure, } \\
\text { target unit margin, resource velocity } \\
\text { - Key resources } \\
\text { - Key processes }\end{array}$ \\
\hline $\begin{array}{l}\text { STOF Model } \\
\text { (Bouwman et al., 2008) }\end{array}$ & $\begin{array}{ll}\text { - } & \text { Service domain } \\
\text { - } & \text { Technology domain } \\
\text { - Organisation domain } \\
\text { - }\end{array}$ \\
\hline $\begin{array}{l}\text { E-Business Model Schematics } \\
\text { (Weill and Vitale, 2001) }\end{array}$ & $\begin{array}{ll}\text { - } & \text { Strategic objectives and value proposition } \\
\text { - } & \text { Sources of revenue } \\
\text { - } & \text { Critical success factors } \\
\text { - } & \text { Core competencies }\end{array}$ \\
\hline $\begin{array}{l}\text { Technology/market mediation } \\
\text { (Chesbrough and Rosenbloom, 2002) }\end{array}$ & $\begin{array}{ll}\text { - } & \text { Value proposition } \\
\text { - } & \text { Market segment } \\
\text { - } & \text { Value chain } \\
\text { - } & \text { Cost structure and profit potential } \\
\text { - } & \text { Value network } \\
\text { - } & \text { Competitive strategy }\end{array}$ \\
\hline $\begin{array}{l}\text { Entrepreneur's Business Model } \\
\text { (Morris et al., 2005) }\end{array}$ & $\begin{array}{ll}\text { - } & \text { Foundation level } \\
\text { - } & \text { Proprietary level } \\
\text { - } & \text { Rules level } \\
\end{array}$ \\
\hline $\begin{array}{l}\text { E3-Value Model } \\
\text { (Gordijn and Akkermans, 2001) }\end{array}$ & $\begin{array}{ll}\text { - } & \text { Actor } \\
\text { - } & \text { Value object } \\
\text { - } & \text { Value port } \\
\text { - } & \text { Value interface } \\
\text { - } & \text { Value exchange } \\
\text { - } & \text { Market segment } \\
\text { - } & \text { Value activity } \\
\text { - } & \text { Dependency path } \\
\end{array}$ \\
\hline $\begin{array}{l}\text { SCM archetypes } \\
\text { (Bocken et al., 2014) }\end{array}$ & $\begin{array}{l}\text { - Technological, social, organisational } \\
\text { - Value proposition } \\
\text { - Value creation and delivery } \\
\text { - Value capture }\end{array}$ \\
\hline $\begin{array}{l}\text { Activity system } \\
\text { (Zott and Amit, 2010) }\end{array}$ & $\begin{array}{l}\text { - New organisational forms } \\
\text { - Ecosystems } \\
\text { - Activity systems } \\
\text { - Value chain }\end{array}$ \\
\hline
\end{tabular}

